\title{
ASSESSMENT OF THE TOURIST RECREATION CAPACITY OF LAKE ALAKOL BASIN
}

\author{
Zhandos T. MUKAYEV* \\ Shakarim University, Department of Science Disciplines, Glinki 20a st, 071412, Semey Kazakhstan, e-mail: zhandos.mukaev@ mail.ru
}

Zhanar O. OZGELDINOVA

L. N. Gumilyev Eurasian National University, Department of Physical and Economical Geography, 2 Mirzoyanst, 010008, Nur-Sultan Kazakhstan, e-mail: ozgeldinova @mail.ru

Kulchikhan M. JANALEYEVA

L. N. Gumilyev Eurasian National University, Department of Physical and Economical Geography, 2 Mirzoyanst, 010008, Nur-Sultan Kazakhstan, e-mail: dzhanaleeva44@ mail.ru

\section{Nurgul YE. RAMAZANOVA}

L. N. Gumilyev Eurasian National University, Department of Physical and Economical Geography, 2 Mirzoyanst, 010008, Nur-Sultan Kazakhstan, e-mail: nurgulram@gmail.com

Altyn A. ZHANGUZHINA

L. N. Gumilyev Eurasian National University, Department of Physical and Economical Geography, 2 Mirzoyanst, 010008, Nur-Sultan Kazakhstan, e-mail: altyn8828@mail.ru

\begin{abstract}
Citation: Mukayev, T.Zh., Ozgeldinova, O.Zh., Janaleyeva, M.K., Ramazanova, Ye.N., \& Zhanguzhina, A.A. (2020). ASSESSMENT OF THE TOURIST RECREATION CAPACITY OF LAKE ALAKOL BASIN. GeoJournal of Tourism and Geosites, $30(2 \mathrm{spl})$, 875-879. https://doi.org/10.30892/gtg.302spl13-517
\end{abstract}

\begin{abstract}
This article proposes criteria for a component-wise integrated assessment of the recreational attractiveness of the landscapes of the Alakol Lake basin. This methodology is based on a component-wise landscape assessment, which consists of the main indicators that make up the landscape: topography, climate, water bodies, and soil and vegetation cover. A comprehensive assessment of the functional suitability of landscapes was carried out. It is in determining the "attractiveness coefficient" for various types of recreational activities. Three types of territories with different degree of recreational attractiveness and functional suitability of landscapes for the further development of recreational activities in the basin of Alakol Lake were identified.
\end{abstract}

Key words: tourism, recreation, landscape, recreational potential, basin, Lake Alakol

$* \quad * \quad * \quad * \quad * \quad *$

\section{INTRODUCTION}

Tourism and recreation have a pronounced orientation to the use of natural resources, and recreational activities do not cover individual components of nature, but the entire natural complex (landscape) as a whole. The significance of the regions for recreational purposes depends on the availability of knowledge of recreational resources: natural, historical, socio-cultural objects that can satisfy the spiritual and other needs of tourists. Identifying tourism attractiveness is not an easy task. Today, there are many methods for assessing the natural recreational potential of a territory. There are methods for assessing tourism attractiveness of regions, which are discussed in studies by Chudy-Hyski (2009), Lisiak et al. (2016), Ziernicka-Wojtaszek and Lisiak (2020), Kerimbay et al. (2020). This article analyzes the state and differential recreational assessment of the landscape components of the Alakol Lake basin.

The basin is an integral natural and economic geosystem, since it is an arena of interaction between nature and society, where natural, economic and socio-demographic processes are interconnected, so it is rational to use the principles of the geosystem-basin concept when solving territorial planning problems (Dzhanaleeva, 2008; Korytny, 2001; Ramazanova et al., 2019). In this way, it is ideal for research and evaluation of the tourist and recreational potential of the selected region. Geographically, the territory of the Alakol Lake basin is located in the south-eastern part of the Republic of Kazakhstan. In the orographic sense, the territory of the basin is represented by the Tarbagatai ridge in the north, by the ridge of Zhetysu (Dzhungarsky) Alatau in the south, by the Barlyk ridge in the east and the southeast. The total area of the Alakol Lake basin is $68,700 \mathrm{~km}^{2}$, the bulk of which $\left(48,600 \mathrm{~km}^{2}\right)$ is located within Kazakhstan, the rest $(30 \%)$ - in the border regions of China (Ivashchenko, 2006). The landscapes of the Alakol Lake basin act as an object for recreational attractiveness assessment. The basis for a landscape map compiling for the region under study was the materials of field studies using existing component maps and literature sources (Medeu, 2010). On the territory of the basin of Lake Alakol, we have identified 68 species of landscapes.

\section{MATERIALS AND METHODS}

Based on the methods proposed by (Sevastyanova, 2008; Kolotova, 1999) we proposed criteria for a component-wise integral assessment of the recreational potential of landscapes. This methodology is based on a component-wise landscape assessment, which is composed of the main landscape components (topography, climate, water bodies, and soil and vegetation cover). The main assessment criterion is the degree of favorableness of landscape components and its functional suitability. There are various methods for assessing natural recreational resources. In our opinion, the most appropriate comprehensive recreational analysis of the territory is to assess the degree of favorability of certain parameters for the recreational use of landscapes. It is optimal to use a three-point system, since it allows you to compare the terrain, climate, water, and soil and vegetation assessment of the territory and obtain a comprehensive characteristic. When assessing the recreational potential of the landscape is the main factor that affects the development of tourism, as well as the aesthetics of the territory.

\footnotetext{
* Corresponding author
} 
Landscape research focuses on holistic approaches, in which landscape is understood as "an area, as perceived by people, whose character is the result of the action and interaction of natural and/or human factors" (Burgi et al., 2017, p. 1372). Landscape determines the aesthetic value-the suitability of space, and as a set of specific properties that determine the development potential of a particular type of recreational activity. From the point of view of landscape diversity, the number of landscapes forming elements (terrain, reservoirs, vegetation), their proportionality, mosaic contours, contrast borders are important. From the point of view of landscape diversity, the number of landscapes forming elements (terrain, reservoirs, vegetation), their proportionality, mosaic contours, contrast borders are important. This article offers a method of component-by-component integral assessment of the recreational potential of the landscapes of the Alakol lake basin. Natural recreational resources were evaluated using a three-point system. The following assessment criteria were used for their characteristics: 3-2,5 points the most favorable resource, 2.4-1.5 favorable resource, 1.4-1 relatively favorable resource.

The assessment was carried out in the following ways:

1. Factor-by-factor evaluation of each parameter separately.

2. Integral-calculation of the average arithmetic score.

The article defines the final estimates for each component of landscapes: topography, climate, water bodies and land cover. The final score was the sum of the scores of the indicators that were used to evaluate it. Assessment of the relief favorability for recreation was carried out in accordance with the scale of recreational assessment of the relief compiled by us based on the materials of Nefedova et al. (1973) and Bredikhin (2004) (Table 1).

Table 1. The assessment scale of the favorable geomorphological indicators

\begin{tabular}{|c|c|c|c|c|}
\hline Relief Description & True Altitude & Surface tilting angle & point & Relief Category \\
\hline Mountain, foothill; crossed: hilly-ridged, ridged-hilly and erosion-dissected & $>1000$ & $>12$ & $3-2.5$ & the most favorable \\
\hline Ridged, stepwise crossed, erosion-dissected, wavy, slightly crossed & $500-1000$ & $6-12$ & $2.4-1.5$ & favorable \\
\hline Flat wavy, flat and mountainous (hard-to-reach surfaces) & $0-500$ & $0-6$ & $1.4-1.0$ & relatively favorable \\
\hline
\end{tabular}

Bredikhin (2004), considers the relief (in the aspect of recreational geomorphology) as a recreational resource that provides rest, i.e. a means of maintaining and restoring ability to work, people's health, satisfying their cultural and aesthetic needs. The relationship between types of recreation and geomorphologic indicators manifests itself in different ways. For example, the presence of mountain systems of different heights with sufficiently high angles of the surface inclination makes it possible to carry out tourist routes of various categories, and the terrain with slight increases is the most suitable for arrangement of therapeutic and recreational vacations. However, for those and other types of recreation cross country is aesthetically most favorable (Garms et al., 2013). For assessing the climatic component of the studied region, we used a scale for the climatic component assessment, which takes into account three main parameters: the duration of a favorable summer recreational period in days, the height of the snow cover, and the sum of air temperatures above $+10^{\circ} \mathrm{C}$ (Table 2$)$.

Table 2. The assessment scale of the climatic component of the territory

\begin{tabular}{|l|c|l|}
\hline Duration of a favorable summer recreational period & Scoring & Quality assessment \\
\hline Less than 70 days & $1.4-1.0$ & relatively favorable \\
\hline $70-80$ days & $2.4-1.5$ & favorable \\
\hline More than 80 days & $3-2.5$ & most favorable \\
\hline Snow cover height & & relatively favorable \\
\hline $10 \mathrm{~cm}$ & $1.4-1.0$ & favorable \\
\hline $25 \mathrm{~cm}$ & $2.4-1.5$ & most favorable \\
\hline More than $25 \mathrm{~cm}$ & $3-2.5$ & \\
\hline The sum of temperatures above $10^{\circ} \mathrm{C}$ & & relatively favorable \\
\hline Less than 2400 & $1.4-1.0$ & favorable \\
\hline $2400-2500$ & $2.4-1.5$ & most favorable \\
\hline More than 2500 & $3-2.5$ & \\
\hline
\end{tabular}

When assessing hydrography, we proceeded from the abundance and diversity of water bodies that determine the possibility of recreational activities arrangement. Territories with a moderately and poorly developed river network have limited opportunities for recreational activities arrangement. Areas with low river density and waterless areas have even greater restrictions.

Assessment of the recreational value of water resources of the Alakol basin was carried out according to the following characteristics: diversity and scale of water bodies, average annual runoff. The scale for the water component assessment for the territory was carried out according to the method proposed by Drozdov (2002) (Table 3).

Table 3. The Criterion for the water bodies assessment

\begin{tabular}{|l|c|}
\hline \multicolumn{1}{|c|}{ Characteristics of water bodies } & Points \\
\hline Absent, either shallow rivers or shallow lakes (1 component) & $1.4-1.0$ \\
\hline Rivers and small ponds, rivers and small lakes, etc. (2 components) & $2.4-1.5$ \\
\hline Rivers, reservoirs, lakes, etc. (3 components or more) & $3-2.5$ \\
\hline The scale of water bodies & $1.4-1.0$ \\
\hline Absent, either shallow rivers, drying streams of upper rivers & $2.4-1.5$ \\
\hline Medium-sized rivers, ponds, small natural lakes & $3-2.5$ \\
\hline Large ones within the region of the river, reservoirs, large lakes & \\
\hline The average annual runoff, mm & $1.4-1.0$ \\
\hline Less than 100 & $2.4-1.5$ \\
\hline $100-140$ & $3-2.5$ \\
\hline More than 140 & \\
\hline
\end{tabular}

We propose to evaluate the land cover of the territories of the Alakol Lake basin using the following parameters: natural zone, forest cover, boggy, and plowed territory. Bogging and tilledness reduces the attractiveness of the area, since it creates additional difficulties in 
organizing routes. We compiled the land cover assessment scale based on the estimates proposed by Drozdov (2002). The plain part of the Lake Alakol basin is predominantly occupied by a desert and semi-desert natural zone, and high-altitude zones are developed in mountainous regions. Subject to the limited organization of various types of recreational activities, we evaluated semi-desert and desert natural zones as relatively favorable, the steppe zone as favorable and forest, forest-steppe natural zones, as the most favorable for recreational use (Table 4).

Table 4. The scale of assessment of land cover (Vedenin et al., 1969)

\begin{tabular}{|l|c|c|c|}
\hline \multirow{2}{*}{ Parameter } & \multicolumn{3}{|c|}{ Soil and vegetation cover } \\
\cline { 2 - 4 } & the most favorable & favorable & relatively favorable \\
\hline Natural area & forest and forest-steppe zone & steppe zone & desert and semi-desert zone \\
\hline Amount of forests \% & more than 15 & $10-15$ & less than 10 \\
\hline Bogginess \% & $1-3$ & $3-5$ & 5 \\
\hline Tilledness \% & 20 & $20-30$ & 30 \\
\hline
\end{tabular}

The integral component score is the sum of the points of those indicators that were used to evaluate it. Ranking was carried out for this amount, and the final assessment of the component was revealed. The integrated assessment of recreational attractiveness is the total value of the above parameters and was calculated by the formula (1) (Kotlyarov, 1978; Kuskov and Golubeva, 2005):

\section{$\mathrm{RA}=\mathrm{TA}+\mathrm{CAK}+\mathrm{WCA}+\mathrm{LCA} / 4$}

where: RA - recreational attractiveness; TA-terrain assessment; CA - climate assessment; WCA - water component assessment; LCA land cover assessment; 4-the total value of the landscape components (RA, TA, CA, WCA). Then, the average values of the recreational attractiveness value for each landscape were found. Based on the data obtained, a corresponding diagrammatic map was compiled. According to the results of the value assessment, three types of territories with different degrees of recreational attractiveness were identified.

Along with assessment of recreational attractiveness, it is important to know the functional suitability of landscapes. A comprehensive assessment of the functional suitability of landscapes is in determining the "coefficient of attractiveness" of landscapes for various types of recreational activities. Functional suitability is the ability of the landscape to provide vacationers with the opportunity to use various types of recreational activities. In identifying the "attractiveness coefficient" of landscapes, we focused on data from literary sources (Kotlyarov, 1978; Kuskov and Golubeva, 2005). The source material for the recreational assessment is a landscape map, and the sum of the possible recreational functions of the studied landscape. The coefficient of functional suitability was determined by us according to the following formula (2) (Kotlyarov, 1978; Kuskov and Golubeva, 2005):

$$
\mathrm{C}_{\mathrm{sf}}=\mathrm{S}_{\mathrm{lf}} / \mathrm{S}_{\mathrm{fr}}
$$

where: $S_{\text {lf }}-$ the sum of landscape features;

$\mathrm{S}_{\mathrm{fr}}-$ the sum of the functions of the region (the Alakol Lake basin as a whole);

$\mathrm{C}_{\mathrm{sf}}-$ suitability factor.

The maximum degree of functional fitness of the landscape is 1 . As a result of a comprehensive assessment of the functional suitability of landscapes for each landscape, the number of types of recreational activities was calculated, i.e. number of recreational functions. We have identified 24 possible functions throughout the Alakol Lake basin (Table 5).

Table 5. Types and functions of recreational activities

Types and functions of recreational activities

\begin{tabular}{|l|l|}
\hline \multicolumn{2}{|c|}{ Types and functions of recreational activities } \\
\hline Scientific and cognitive function & geological - geomorphological objects; hydrogeological; botanical and zoological; archaeological and historical-ethnographic \\
\hline Healing and treatment function & climatotherapy; balneotherapy; mud therapy; koumiss treatment \\
\hline Sports function & $\begin{array}{l}\text { hunting \& fishing; picking mushrooms, berries and medicinal herbs; boat and jet skiing; paraplane (parasailing); windsurfing; } \\
\text { kitesurfing; rowing; rafting; equestrian tourism; hiking (trekking) cycling; caravanning (jipping); mountain climbing }\end{array}$ \\
\hline Wellness function & bathing and beach; sun baths; health resort (treatment with mud, hydromineral springs, honey, berries, herbs) \\
\hline
\end{tabular}

\section{RESULTS DISCUSSIONS}

According to the results of a component-wise integrated assessment of the territory, three types of territories with different degrees of attractiveness for recreational activities were identified in the studied region: the most favorable, favorable territories, relatively favorable. The compiled map shows the spatial distribution of landscapes and helps to identify areas with the most favorable conditions.

The map analysis showed that the most attractive recreational resources are concentrated on the northern slope of Zhetysu Alatau and the southern slope of the Western Tarbagatai ridge (Figure 1). The mountain natural conditions differ in comparison with the plains by it great diversity. This is reflected in the landscape mosaic, and, consequently, in landscape diversity. The northern slope of the Zhetysu ridge is characterized by a sufficiently rugged relief and the predominance of spruce forests and is sufficiently provided with water bodies. Therefore, these territories are the most favorable for all forms of nature-oriented and active types of recreation. The most favorable territories in Zhetysu Alatau are mainly within the middle mountains, and also partially in the low-mountain and high-mountain zones and occupy $30.6 \%$ of the territory. The most attractive landscapes are in the valleys of the rivers Tentek, Tastau, Koksuat and the forested slopes of Zhetysu Alatau. Favorable territories include the southern slope of the Tarbagatai ridge, hilly-ridged loessial foothills of Tarbagatai and Barlyk, alluvial-proluvial foothill inclined plains of Zhetysu Alatau, the Barlyk, Miley and Tarbagatai ridges, alluvial and lake-alluvial plains. Barlyk-Arasan piedmont region - occupies semi-desert and desert natural zones. The area is favorable for the development of health tourism. The relief characteristic of the adjacent territory to the Barlyk-Arasan sanatorium is favorable for laying all types of terrain paths. The intermountain lake-alluvial plains adjacent to the water areas of Lake Alakol are characterized by a high level of recreational potential and are favorable for the development of various types of recreation and tourism. Tourist and recreational potential is favorable for beach recreation, many types of water tourism are developed.

Relatively favorable territories are desert and semi-desert landscapes located in the western part of the Alakol Lake basin, as well as the territories of ridged-tuberous sands, which occupy $26 \%$ of the total area. Desert and semi-desert landscapes of plains have the least aesthetic value. Also, along with an assessment of recreational attractiveness, the coefficients of functional suitability of the landscapes of the Alakol Lake basin were identified. The results of the recreational assessment of the obtained parameters were entered into the 
general summary table as the sum of the landscape functions and subsequently the functional suitability coefficient was derived by the formula (2). The calculations allowed us to draw the following conclusions:

1. Areas where the fitness factor is up to 0.1 are the least suitable for recreation. These areas are semi-desert and desert landscapes of the western part of the Alakol Lake basin. The landscape attractiveness of this territory is low and has the least aesthetic value. Due to the vastness of the territory, insignificant horizontal dissection of the relief and the lack of water bodies, the most acceptable type of recreational activity is auto-tourism (caravanning).

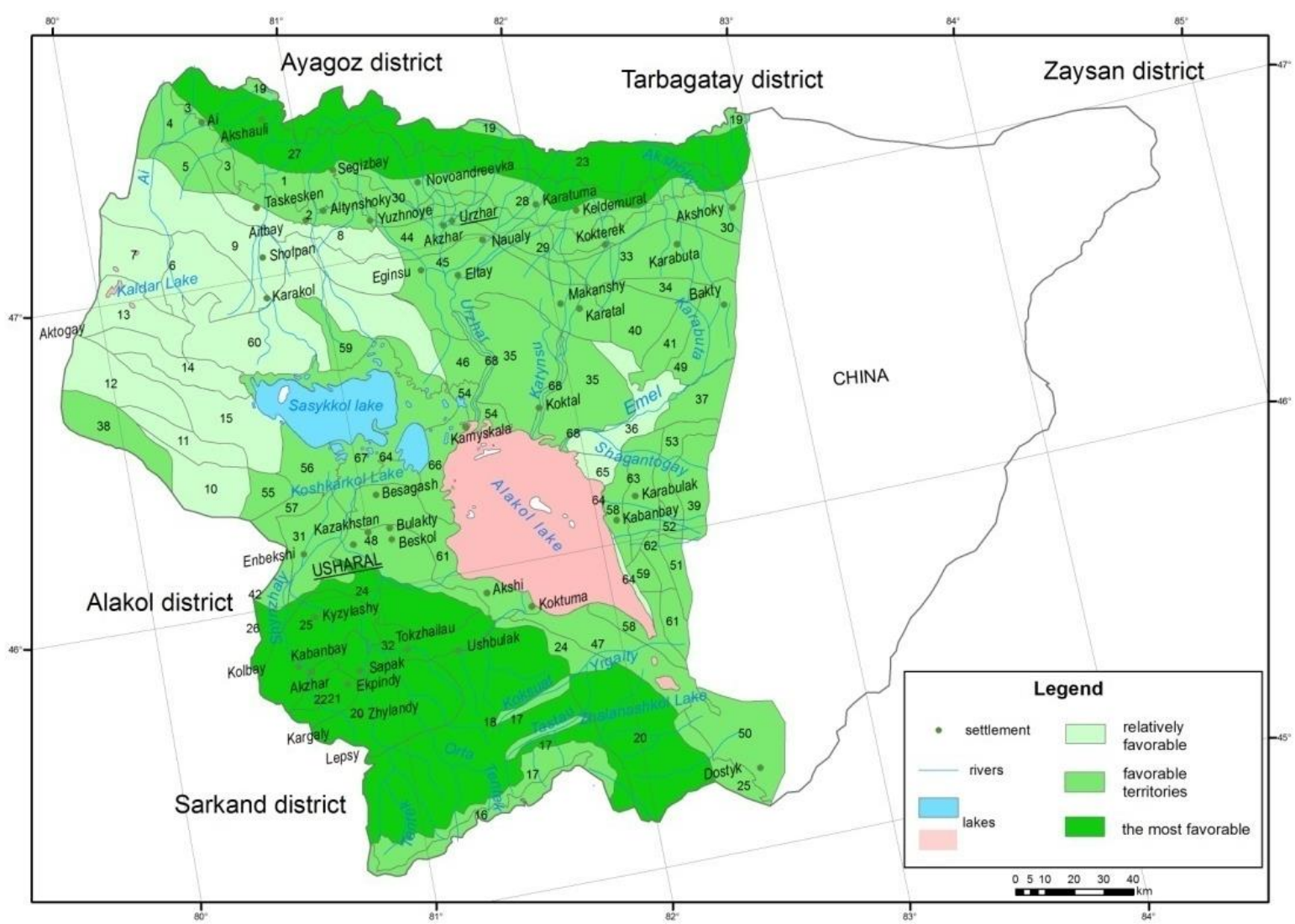

Figure 1. Map of the tourist and recreational potential of the Alakol Lake basin (Source: Mukayev, T.Zh.)

2. Areas suitable for recreation with a coefficient from 0.1 to 0.5 : Mountain and foothill landscapes of Zhetysu Alatau and Tarbagatai. Mountain and foothill landscapes are characterized by a variety of recreational functions. Here you can see the change of high-altitude landscape zones: semi-desert, mountain-steppe, mountain-forest, alpine. Along with a variety of nature-oriented functions in mountain landscapes, it is possible to develop such types of sports functions as: close watching of rare animals and birds, picking mushrooms, berries and medicinal plants, hiking (trekking), cycling (mountain biking), mountain climbing, etc.

3. The most suitable landscapes with a coefficient above 0.5. These are intermountain lake - alluvial plains adjacent to Alakol Lake (Kabanbay, Akshi, Koktuma, Koktal). The territories adjacent to Alakol Lake are favorable for the further development of beach and bathing vacations. To reduce the load on existing beaches, it is advisable to organize additional necessary infrastructure for beach and bathing vacations, such as clearing water approaches, equipping beaches with umbrellas and changing cabins, opening new rental points for sports equipment.

Along with a beach-bathing holiday, a high coefficient of landscape suitability is affected by the presence of hydromineral springs in the Barlyk-Arasan sanatorium complex in the vicinity of Alakol Lake and therapeutic mud in the coastal zone of the lake. The use of ther apeutic mud of Alakol Lake is of great interest. It is used in the treatment of various diseases of the joints, radiculitis, skin ailments, and recovery from injuries. Monuments of the early Iron Age are located in the area: Aksha burial grounds and monuments of the Middle Ages - the ancient settlements of Usharal and Koktuma, which are of significant importance. There are also favorable conditions for the development of nature excursions to the unique lakes of the Alakol-Sasykkol group, to nesting sites for waterfowl, figure 2. As a result of analyzing factors and conditions that contribute to the development of recreation, we have assessed the degree of favorability and functional suitability of landscapes in the Alakol lake basin. As a result, a significant number of areas were identified that are suitable for various types of recreational activities. Landscapes depending on the terrain, climate, water bodies, soil and vegetation cover, as well as the suitability of the landscape for recreational activities were combined into recreational zones. There are 3 recreational zones on the territory under study. 1 . Intermountain lake-alluvial recreational zone. 2. Zhetysu and Tarbagataiskaya mountain recreation area. 3. Western lowland recreation area.

\section{CONCLUSION}

Analysis of drawn cards and the data on usefulness and suitability of landscape study of the region allow to draw the following conclusions: the most suitable for tourism and recreation, are intermontane lacustrine-alluvial plains adjacent to the lake Alakol relate to the favorable areas, which have the greatest functional suitability for various types of recreational activities. The recreational potential of the Lake Alakol is of interest for the development of therapeutic, recreational and sports activities (bathing, beach, spa, thera peutic, sports) due to favorable climatic conditions. Most vacationers at the Lake Alakol prefer a bathing and beach holiday. Here, vacationers can receive a wide variety of types of health and sports recreation: bathing, sunbathing, balneotherapy, jet skiing, paragliders walk along the shore etc.

The most favorable territories are concentrated on the northern slope of Zhetysu Alatau and the southern slope of the Western Tarbagatai ridge. According to the functional suitability of the landscapes, the middle mountains of Zhetysu-Alatau and Tarbagatai are assigned to 
favorable areas that create the potential for various types of recreational activities: tourist-excursion, ecological, scientific and educational, mountain tourism, mountain climbing. In the mountains of Zhetysu Alatau there are a sufficient number of mountain rivers Tentek, Koksu, which are recreationally attractive objects for rafting and for sports functions.

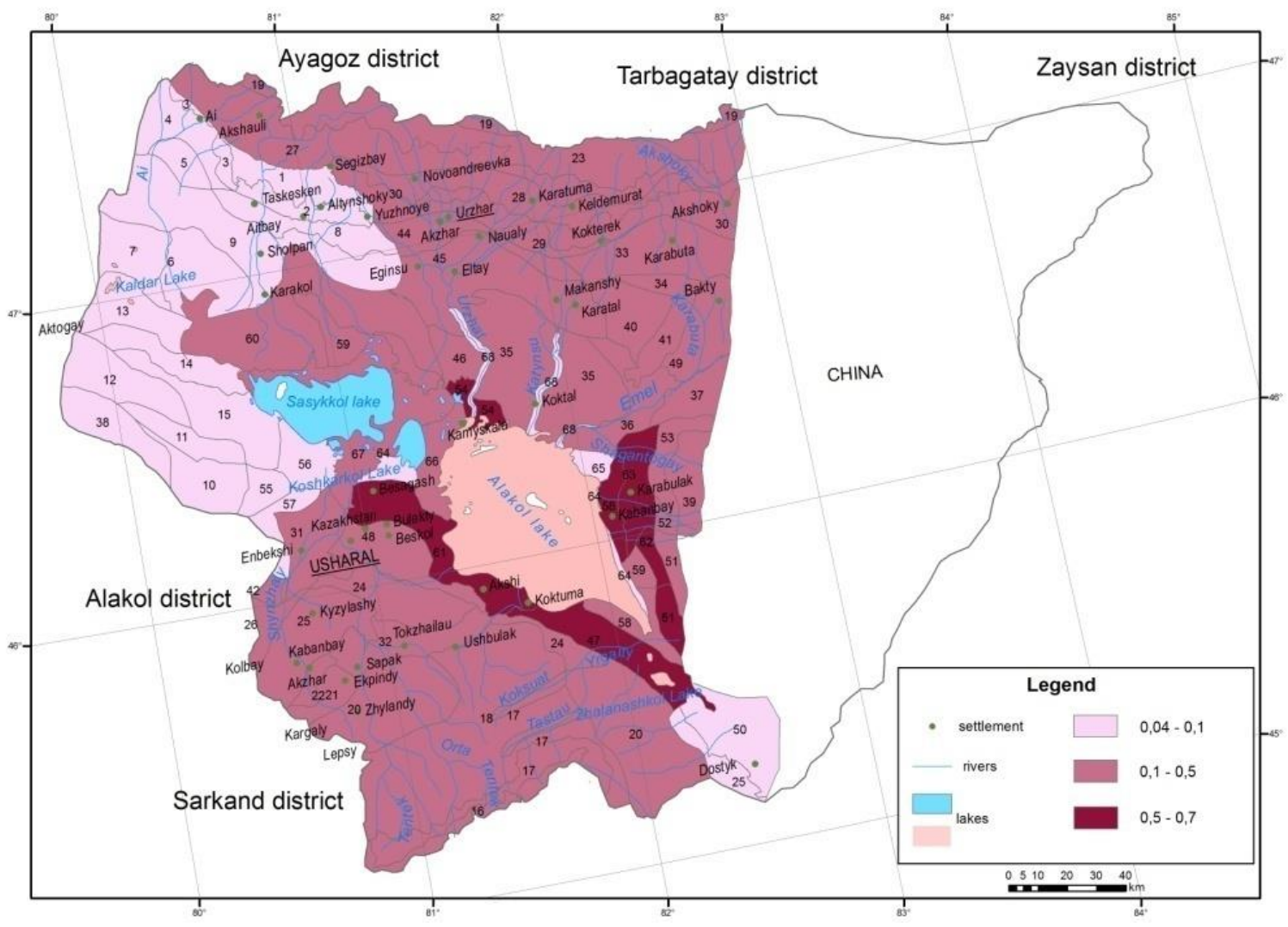

Figure 2. Map of the functional suitability of Alakol Lake basin (Source: Mukayev, T.Zh.)

Relatively favorable territories include desert and semi-desert landscapes located in the western part of the Alakol Lake basin. Landscapes are less favorable due to the weaker ruggedness of the surface. Along with relatively favorable indicators, there are the lowest indicators of functional suitability in desert and semi-desert landscapes of the western part of the Alakol Lake basin. Considering the peculiarities of this region, the most acceptable type of recreational activity is auto-tourism (caravanning). Natural and climatic conditions do not contribute to the development of recreational activities and are more suitable for agricultural use.

\section{REFERENCES}

Bredikhin, V. (2004). Relief as a recreational condition and a tourism resource. Bulletin of Moscow University. Series Geography, 4, $23-28$.

Bürgi, M., Ali, P., Chowdhury, A., Heinimann, A., Hett, C., Kienast, F., \& Verburg, P.H. (2017). Integrated landscape approach: closing the gap between theory and application. Sustainability, 9(8), 1371.

Chudy-Hyski, D. (2009). Uwarunkowania turystycznego kierunku rozwoju gyrskich obszaryw wiejskich Polski [Conditions of mountain rural areas in Poland development through tourism]. Infrastruktura i Ekologia Terenyw Wiejskich, No. 2009/1 p. 309 (In Polish).

Drozdov, A. (2002). Ecological and tourist potential of the Russian regions. Materials of II international scientific conf. Actual problems of geoecology. Problems and prospects for the development of tourism and recreation in the Volga region, 2, 220-221.

Dzhanaleeva, G. (2008). Theoretical and methodological problems of geography, 225, Astana.

Garms, Ye., Khromykh, V., \& Sukhova, M. (2013). The use of GIS in the assessment of geomorphological resources for recreation (for example, the transboundary Gorny Altai). Modern problems of science and education, 6, 1-7.

Ivashchenko, A. (2006). Nature reserves and national parks of Kazakhstan. Almaty Almaty Kitap, 284 p.

Kolotova, Ye. (1999). Recreational Resource Management, RMAT,135.

Korytny, L. (2001). Basin concept in nature management: monograph. Publishing house of the Institute of geography, 163.

Kotlyarov, Ye. (1978). Geography of leisure and tourism. Formation and development of territorial recreational complexes, 238.

Kuskov, A., \& Golubeva, V. (2005). Odintsova T. N. Recreational geography: textbook.-method. complex, 496.

Kerimbay, B.S., Janaleyeva, K.M., \& Kerimbay, N.N. (2020). Tourist and recreational potential of landscapes of the specially protected natural area of sharyn of the republic of Kazakhstan. GeoJournal of Tourism \& Geosites, 28(1), 67-79.

Lisiak, M., Opala, A., \& Borowiak, K. (2016). The concept of tourism development as a factor increasing the tourism potential of rural communes-a case study. Studia Obszarów Wiejskich, 43, 99-112.

Nefedova, V., Smirnova, Ye., \& Shvidchenko, L. (1973). Methods of recreational assessment. Bulletin of Moscow State University. Series Geography, 5, 25-29.

Medeu, A. (2010). The National Atlas of the Republic of Kazakhstan, 100-121.

Ramazanova, N., Berdenov, Z., Ramazanov, S., Kazangapova, N., Romanova, S., Toksanbaeva, S., \& Wendt, J. A. (2019). Landscape-geochemical analysis of steppe zone basin Zhaiyk. News of the National Academy of Sciences of the Republic of Kazakhstan, series of Geology and Technical Sciences, 4(436), 33-41.

Sevastyanova, S. (2008). Ecological and economic assessment of recreational resources, 190.

Vedenin, Yu., \& Miroshnichenko, N. (1969). Assessment of natural conditions for recreation. News of the USSR Academy of Sciences. Geographical series, 4, 51-60.

Ziernicka-Wojtaszek, A., \& Lisiak, M. (2020). Evaluation of the tourism and recreational space of Lubaczowski County, Poland. Journal of Water and Land Development, 165-172. 